\title{
The Roles and Responsibilities of Church on Christian Education Teachers Unavailability Handling for Elementary School in Cikampek Regions
}

\author{
Christina Metallica Samosir
}

\author{
Christian Religious Education, Faculty of Teacher Training and Education, Universitas Kristen Indonesia \\ Christina.uki@uki.ac.id
}

\begin{abstract}
The Unavailability of Christian education teacher (PAK) in the public schools has been a problem in Cikampek. The few numbers of Christian students in the school is the reason not accept for the teachers. By dealing with these conditions the author saw that the Church needs to act and take responsibility in solving the problems of schools that do not have teachers (PAK). This study aims to determine the role of the church to PAK, the challenges PAK at school and how should the church respond the problems. The method used in the study was a descriptive study using a qualitative approach. As a study conducted in the Batak Christian Protestant Church (HKBP) Cikampek, Western Indonesian Protestant Church (GPIB) Cikampek, Sundanese Christian Church (GKP) Cikampek, Elementary School (SD) East Dawuan II and Elementary School (SD) Middle Dawuan V. This study was carried out to the Pastor/Church Assembly, the Council of Diakonia, a Sunday school teacher (BC), the principal, and parents. The findings of this study indicate that the PAK is a learning tool that facilitates every learner to know God through His works and to realize the knowledge of the Trinity of God through a life attitude which refers to Christian values. It is intended that the students involved in the learning process of calling PAK has to realize the signs of the kingdom of God in the lives of individuals and as part of a community. Thus the church as a container PAK needs to play a role and be responsible for the absence of PAK teachers in schools, especially public schools. The Church should pay very serious attention this condition. PAK is not the needs and interests of the institutional church, but the needs and interests of learners functional and existential.
\end{abstract}

\section{Keywords: Christian Religious Education, Church, School Problems}

\section{INTRODUCTION}

The form of church discussion that was pioneered by the church in the Middle Ages XVIII was Christian Religious Education (PAK) in Sunday school. Robert Raikers was the first person to establish a Sunday School (SM), he was concerned about various social ills that fight and oppress people. Raikers' concern (Boehlke, 2005, p. 383) arises after revealing the mother expressing anxiety and says: other people that does not mean any good person on earth, instead he has entered into the disaster. "Raikers continues to conclude that to overcome various social ills in society aimed at children there must be a solution. According to Raikers, in children, there be potential to fulfill the country. Children have "unique potential" in various fields such as science, natural sciences, social sciences, literature and languages, and wealth to face life. These potentials are a benchmark in realizing a high civilization. Through SM various children's potentials can be realized, not only regarding spiritual morals but also in the intellectual, social, emotional, and other fields. SM has become a forum for preaching at this time SM remains one of the forums for the church in the discussion.

Theologically, PAK is part of education that covers all age levels (from the womb to the tomb) and all professional categories. This requires that they grow in the knowledge and appreciation of the Christian faith and be able to live in a bright faith in the midst of daily life. Eka Darmaputera put forward "Christian faith" as a keyword in PAK. According to Eka, Christian faith must be communicated, lived, and confronted with the reality of daily life in PAK. Christian faith is the basis and starting point that gives content and style to determine the Direction and The target of PAK (Anon., 1997, p. 3). Therefore, PAK is the full authority and responsibility of the church. PAK in school is a form of Christian religious education besides PAK in the church, and in the family. PAK in the church consists of BC, catechism, PAK Adults and the elderly, while PAK in the family is carried out in 
the form of Bible Study (PA) worship and discussions that end with worship. Often PAK in the church gives less priority to the implementation of PAK in schools, especially in public or private schools. This happens because the church considers that PAK in school is the responsibility of the school/government, not the church.

\section{RESEARCH METHODS}

Seeing the number of research sites to be conducted, the author finally limited the 3 (three) research sites, including the Huria Christian Batak Protestant (HKBP) Cikampek, Jln. Kamojing East Ciluwek No. 1 Cikampek Selatan, Western Indonesian Protestant Church (GPIB) Shalom Congregation, Jln. Kamojing, Gang of Youth Development No. 3, Pasundan Christian Church (GKP) Ebenezer, Jln. General Ahmad Yani, Cikampek. The research will be held for 3 (three) months, from June to August 2015. This research will be conducted to the Pastor, Diaconia Assembly Council, SM Teachers, Principals, and Parents (congregations). The research method that I use is descriptive research that uses a qualitative approach.

\section{RESULT}

\subsection{PAK in Indonesia}

Christian Religious Education (PAK) in Indonesia is an absolute part of the embodiment of the mission of the church through "education" in the broadest sense as well as in a special sense concerning family, school, and society. This can be seen how through PAK students learn and interpret the love of God in themselves and their lives and go in the right direction on the fulfillment of God's will. This can be done well if the family, school, and community (church) can know and understand the nature, functions, dimensions, and regulations of PAK in schools.

The implementation of PAK refers to humans as God's creations, namely: 1) creations that are pictured and similar to God (imago DEI / image of God); 2) creations which have the essence and social responsibility; 3) creations have given natural abilities to be able to carry out their vocation as human beings of faith, as a part of social, and cultural community.

To realize the mission mentioned above, PAK is built on the foundation of the Bible as a source of wealth of wisdom and knowledge. Thus PAK serves to guide humans as individuals and groups who are always alive and express their existence to glorify His creator. Life serves fellow humans with love and truth based on Christ's sacrifice; and accountable for his service to God.

Thus, through PAK, students live and define God's love in themselves and their lives, and go in the right direction to fulfill God's will. That is why the church is responsible for PAK at all levels and channels of education, both formal and informal. In fact, all church activities essentially contain the PAK dimension, so the implementation of PAK must be centered on the gospel message as Good News. In addition, PAK is also oriented to the vision and mission of the church and is centered on the service needs to provide content and meaning for the lives of church members as citizens.

\subsection{PAK in Schools}

RI Government Regulation (PP) number 55 of 2007 states that religious education is education that provides knowledge and shapes the attitudes, personalities, and skills of students in practicing their religious teachings which are carried out at least through subjects in all lines, levels, and types of education. PAK becomes an integral part of national education which aims to improve the quality of Indonesian people. Namely people who have faith and devote to God Almighty, noble character, personality, independent, advanced, tough, intelligent, creative, skilled, disciplined, ethnically working, professional, responsible and productive and productive, physically and mentally healthy. In other words, education is directed at increasing the intelligence and dignity of the nation in realizing an Indonesian society that is faithful and devoted to God Almighty and can meet the needs of national development that is responsible for national development. In a collection of essays around PAK, Posumah (Ismail, 2003) raises the question of whether PAK in schools is held solely to meet the demands of national education? Although in the end, PAK will fill national education targets, what must be the main motivation is always teaching, changing and humanizing humanity. Also, an awareness that the nature of God the Father, the Son, and the Holy Spirit is the Teacher and Educator who drive the PAK process. As the task of the Church's vocation in carrying out the gospel, PAK is the responsibility of the church. In the PAK there is a proclamation of the gospel but PAK needs to be distinguished from the gospel message (PI) because it has a specific strategy, method, and purpose of each. But indeed both have a connection in that the teaching and preaching of the gospel is a task mandated by Jesus Christ to his apostles and disciples.

PAK in schools is held at every level of education from kindergarten to tertiary education (both general and vocational) as a compulsory subject. PAK becomes 
an integral part of national education which aims to improve the quality of Indonesian people. Namely, people who have faith and devotion to God Almighty, noble character, personality, independent, advanced, tough, intelligent, creative, skilled, disciplined, ethnically working, professional, responsible and productive and productive, physically and mentally healthy.

\subsection{Challenges of PAK in Schools}

Tilaar (in Tan Giok Lie: 2015) said that education, in general, is closely related to the changing times of the 21 st century globalization era, as well as Christian education. The following is an illustration of the challenges of PAK in the 21st-century globalization era, including (Tilaar, 1998):

1. The existence of various shifts in the values and paradigms of life due to the ongoing process of globalization that is very fast and comprehensive both science and technology, information, professionalization, mentality, norms, values that directly or indirectly have an impact on the field of ideology, politics, socio-cultural, economic, educational, and religious which in itself will have an interest in humans as church members and citizens who are targets of PAK;

2. The existence of turmoil of changes that are very fast, sharp and alarming concerning the paradigm shift of life from modernism to post-modernism that has an impact on ways of thinking, acting, and lifestyle, including religious lifestyles. Various symptoms of post-modernism have emerged that tend to manifest shifts and even distortions of truth values from absolute to values that is relative, cultural, temporal, artificial, artificial, secular, hypocritical, fake, imitation and so on which are vague and difficult to distinguish good and bad, and contrary to biblical truth;

3. The strong flow of information in various forms and characteristics that make humans dependent and fascinated with various worldly offers and the advantages of science and technology. Cultural penetration through various media, greatly influences the affective area of church members, especially the younger a generation who tend to be easy to accept, try out, join in on cultural values outside;

4. There are still many religious education and learning processes that are classical, traditional, conservative, indoctrination, moralistic, dogmatic, and teacher-centered that are no longer in accordance with the growth and development of the life world of students, so that they are unable to answer the needs of real and contextual problems of the protege. Thus, this condition can create boredom and reactive nature of students which in turn gives them the opportunity to prefer to follow religious lessons through other forms and forums, including through communication media, which are more interesting and easily absorbed;

5. Another impact of globalization which is very strong to lead people toward individualism due to the demands and the necessity to compete and expand marginalization both individually and in groups. Directly or indirectly, this the condition has the potential to penetrate the lifestyle of young people in particular and church members in general. Meanwhile, the church tends to be left behind and is even unable to get out of the old pattern which makes it unable to position itself and play a proactive role in the speed of change in its environment and the world. In this context, PAK must be able to instill and revive the understanding of Christian values in order to be permanent and stable to be applied to everyone who has an interest in PAK both in churches and educational institutions;

6. The potential of human resources with an interest in PAK, both in churches and in educational and developmental institutions, both in terms of quantity and quality are generally inadequate or even very limited and limited. The church is challenged to be more serious and planned to improve the quality and quantity of human resources and other resources for PAK, both through the procurement process, especially in terms of financing and in terms of increasing potential.

The challenge is a disruption or obstacle that occurs due to a mismatch. Similar to the challenges faced by students when PAK is not taught in schools, students do not understand the basic principles of Christianity. But when referring to the law on the national education system, Chapter V Article 12 No.1 clearly states that every student in each education unit is entitled to receive religious education in accordance with the religion he follows and is taught by educators of the same religion. Schools that do not provide PAK teachers by themselves clearly violate the mandate of the National Education System Law no. 20 of 2003 Article 12 No.1 a.

\subsection{Characteristics of PAK Subjects in Schools}

Janse Belandina et al. (2013:7) says that Christian Religious Education (PAK) is the responsibility of families, churches and formal schools. The three 
institutions have their own target achievements, although the three cannot be separated. The implementation of PAK in schools is under the coordination of the Ministry of National Education (Kemendiknas) and the Ministry of Religion of the Republic of Indonesia (Kemenag RI), but the contents of the teachings (dogma) are left to the church. Therefore synergy between families, churches, and schools needs to be continued (Belandina Non et al., 2013, p. 7).

The implementation of PAK today faces significant challenges regarding various developments that can affect the lives of the faith and spirituality of Indonesian Christian children. In the life of the nation and state we face complex problems, such as conflicts that are often accompanied by violence, the danger of national disintegration or disintegration, human rights violations, social injustice, harassment of the law, discrimination against marginalized communities, violence against women and children, reform and democratization which was alleged "the way in place", and poverty which increasingly made the life of this nation worse. Through PAK, it is hoped that students will not only fulfill their spiritual needs but also gain enlightenment in life. Through enlightenment, they are able to find solutions to various real problems in their lives. PAK curriculum development is as much as possible able to help students to be ready and able to face and find solutions to the various problems that have been described above.

PAK is a vehicle for learning that facilitates students to get to know God through His work and realize their knowledge of the Triune God through attitudes that refer to Christian values. Thus, through PAK students experience an encounter with God who is known, trusted and believed. The encounter is expected to be able to influence students to grow into salt and the light of life.

\section{CONCLUSION}

Based on the findings of the research, the authors conclude that the school is essentially an educational and teaching institution that is public and open. The school functions to meet people's needs for education and teaching (which is general) from any religious / religious / ideological background. Public schools in the surrounding Cikampek area still consider the absence of PAK teachers not to be the main focus in education. Schools view that PAK is the church's full duty and responsibility. The factor of the absence of PAK teachers is the impact of social conditions that are not supportive. This is more complex when the government, in this case, the local education office is not serious about seeing the problem and anticipating it. Especially if the church is less aware that the absence of PAK teachers in schools, in the long run, has a very serious impact on children's faith education. The motto that children are the future of the nation and the church cannot be realized if children's faith education is neglected. This is important because faith is the basis for forming one's attitude. Children who get good faith education and continue to be able to turn themselves into hopes for the future of the nation and church. Schools that do not provide PAK teachers for their students have violated the National Education System Law no. 20 of 2003 Article 12 No.1 clearly states that every student in each education unit is entitled to receive religious education in accordance with his religion and taught by educators of the same religion. Not only in public schools, but also in the private sector that every student has the right to get religious studies in accordance with their religion. So the government is obliged to provide / appoint religious teachers for all students in accordance with their religion. As confirmed in Chapter 1 part that the church is present in the world carrying God's mission (Missio Dei) to humans and the world in general and one of the important missions of the church is PAK. When the church tends to ignore PAK, the church has ignored its mission to humans and the world at large. For this reason, the church needs to play a proactive role and take responsibility for overcoming the absence of PAK teachers in schools, especially state schools. The church must pay very serious attention to these conditions. PAK is not the church's institutional needs and interests, but the students' functional and existential needs and interests.

\section{REFERENCES}

[1] Anon., 1997. PAK in Indonesia. Salatiga: Christian Counseling Body Foundation Foundation in Indonesia.

[2] Belandina Non, et al., 2013. Teacher's Guide to Christian Religious and Character Education (as Supporting Document for 2013 Curriculum). Jakarta: Ministry of Education and Culture Research and Development Agency Curriculum and Book Center.

[3] Boehlke, R., 2005. History of the Development of the Mind and Practice of Christian Religious Education. Jakarta: BPK Gunung Mulia.

[4] Ismail, A., 2003. Teach them to do. Jakarta: BPK Gunung Mulia.

[5] Naibaho, L. (2014). The Role of Education and Culture in the Development of Character and 
Civilization of the Plural Indonesian Nation. Jurnal the Ary Suta Center Series on Strategic Management, 27(0), 69.

[6] Tilaar, H., 1998. Some Agenda for National Education Reform: In the 21st Century Perspective. Magelang: Tera Indonesia.

[7] Tyas, E. H., \& Naibaho, L. (2020). Building a Culture of Tolerance since Early Childhood. International Journal of ResearchGRANTHAALAYAH, 8(8), 244-249.

[8] Tyas, E. H., \& Naibaho, L. (2020). A harmony among of religious community is required amidst the covid-19 pandemic. International Journal of Research-GRANTHAALAYAH, 8(9), 422-428. 